\title{
Identity Crisis in Martin Amis's Money and London Fields
}

\author{
Abdelrahman J. Othman ${ }^{1}$, Rebwar Z. Mohammed ${ }^{2}$ \\ ${ }^{1}$ Department of English, Faculty of Arts, Soran University, Kurdistan Region, Iraq \\ 2 Department of Translation, College of Languages, University of Sulaimani, Kurdistan Region, Iraq \\ ${ }^{2}$ V. P. For Scientific Affairs and Postgraduate Studies, Cihan University Sulaimani, Kurdistan Region, Iraq
}

\begin{abstract}
Martin Amis's novels are known for their representation of the dilemma of human beings in facing the problems of their age. Problems that may lead them to the status of crisis and expose them to sever psychological pain. This paper deals with issues related to identity and the traumatic conditions of the characters in two of Martin Amis's outstanding novels which are Money and London Fields. Using a descriptive analytic approach, I will be highlighting how these characters pass through a status of crisis while living in an era of material idolization and greed that results in death of love and human noble emotions which consequently lead them to the verge of apocalypses. Although the setting of these novels are United Kingdom (UK) and the United States of America (USA), the author wants to present the case as an international problem that may affect human life in different places of the world. Through a harsh language and a realistic manifestation, Amis is disclosing the true face of modernity which apparently is very attractive but deep inside is full of atrocities and disaster. I will also indicate how some of the main characters overcome the challenges they face and are able to find out their lost identities after paying high prices both emotionally and psychologically.
\end{abstract}

KEY WORDS: Identity Crisis, Martin Amis, Modernity, Psychology, Trauma

\section{INTRODUCTION:}

Martin Amis (b.1949) is having a special place in academic and literary circles of his time and according to Encyclopedia Britannica, he is "one of the best-known public intellectuals of the late 20th and early 21st centuries" (Britannica, 2020). Early in his life, he managed to have a distinctive style of writing which, according to Brian Finney (2008), is "to see himself as representative of a generation" who found themselves entrapped by "a drastically deteriorated stage of modernity" (p. 1). This is why his works attract many

Koya University Journal of Humanities and Social Sciences (KUJHSS), Volume 4, Issue 1, 2021.

Received 23 Jan 2021; Accepted 13 Mar 2021, Regular research paper: Published 30 Jun 2021

Corresponding author's e-mail: rebwarzainadin@gmail.com Copyright (O2021. Abdelrahman J. Othman, Rebwar Z.

Mohammed, this is an open access article distributed under the Creative Commons Attribution License. readers.

His fictional writings are characterized by harsh criticism of the social and, in some cases, political conditions of the humans in the urban contexts of the metropolitan cities. John Haffenden (1985) believes that "his novels, with their witty treatment of a sick society, arouse as much hot critical debate as the personality fostered by the media" (p. 1). Despite criticism from some critics including his father, Kingsley Amis (19241995), at least at the beginning (Keulks, 2006, p. 10), Martin Amis's novels were included among the best sellers which is an indication of acceptance and appreciation by the public.

Most important of Amis's novels are those of 1980s especially Money and London Fields which are seen by many critics to reflect the government policies of that time. Amis, in his works, does not hesitate to tackle any human problem including what may seem for some people to be "catastrophe and obscenity" (Mulalić, 2015, p. 66). The novelist tackles the violent incidents happening in the streets of his own town in an 
innovated and attractive language. In these two novels, he depicts the crisis of identity for the modern man towards the end of the twentieth century. The background of the novels is set against hilarious changes taking place in the modern time that impact human life drastically. To this end, Stephen Frosh (1991) describes the era as been "characterized by uncertainty, rapidity of change and kaleidoscopic juxtapositions of objects, people and events" (p. 7). Events that may lead humans to the verge of pathological status of mind.

Both novels are published in 1980s (Money in 1984 and London Fields in 1989) which is a time of some unprecedented changes like the constant nuclear threat between the United States and the former Union of Soviet Socialist Republics (USSR) before the latter's collapse in 1991; the fall of Berlin wall in 1989; Chernobyl nuclear accident 1989; formalization of the concept of World wide Web; and many other significant social and economic changes. No doubt that these changes would leave a huge psychological impact on the humans who have to adapt themselves in every aspect of life to the new possibilities. Anthony Giddens (1991) calls these new possibilities "a post-traditional order" in which "doubt, a pervasive feature of modern critical reason, permeates into everyday life as well as philosophical consciousness" (p. 3). The uncertainty of what may happen next is what makes modern humans live in a position of instability and crisis.

Life in modern time is an amalgamation of infinite contradictory ideals that is difficult to be overcome yet it is inevitable and cannot be avoided. Humans are wondering between the extremes and trying in vain to find a logical explanation for the new conditions they find themselves plagued in. For Marshall Berman (1982), modernity is "an environment that promises us adventure, power, joy, growth, transformation of ourselves and the world-and, at the same time, that threatens to destroy everything we have, everything we know, everything we are" (p. 15). Modernity, in this sense, may take away from humans more than it offers them.

\section{MATTER-INFECTED SELVES}

Martin Amis's Money is a depiction of the modern life in the late twentieth century. It is a direct representation of the private and public life of a protagonist named John Self who crisscrosses London and New York in search of money. Self spends his time in hedonistic behaviors restricted to "fast food, sex shows, space games, slot machines, video nasties, nude mags, drink, pubs, fighting, television, hand ${ }^{* * * *}$ [asterisks are mine]" (Amis, 1984, p. 67). All the stated activities are the outcome of rampant consumerism happening in late twentieth century propelled by the money-greed ideology of the time. This is the spirit of the age, guided and directed by power institutions beyond, and usually above, the ordinary individuals like John Self. Life is so difficult and so void of any spiritual taste that it resembles the life of animals in the wild because the ordinary people are chased and strangled to death by what Amis calls them "moneymen". This condition is not restricted to a specific place in the world, it is rather a world condition. London, as been described by Self, is no better than New York. It has been referred to as having "culture shock. Self is comparing his living condition in these two cities to the life of animals when he says, "I live like an animal-eating and drinking, dumping and sleeping, $\mathrm{f}^{\star * *}$ ing and fighting [asterisks are mine]" (Amis, 1984, p. 257). This is all because of the human greed and the idolization of the materialistic life in which everything is measured against money. Amis is very carefully exposing this issue by criticizing the government policy that, in Daniel Lea's (2005) words, "advocated a free market economy with limited state intervention" (p. 71).

The harsh economic condition of low-income people is depicted through the narrator's girlfriend, Selina Street. The narrator states that "many times in her life she has lacked the price of a busfare, a teabag. She has stolen. She has pawned clothes. She has $\mathrm{f}^{* * *}$ ed for money. No money hurts, it stings [asterisks are mine]" (Amis, 1984, p. 88). Based on this, getting a lot of money is linked to non-ethical means including some sort of illegal transactions like drugs, gambling, and porn industry which are usually run by smugglers and addicts who have no education and are void of any sense of humanity. However, this is neither the condition for Self only nor it is the case with his country alone. It is rather a world condition because "so is the United States. So is Russia. We are all stomped and roughed up and peed on and slammed against the wall by money". The contest is so terrible that, as Amis states, humans "ought to shake money like a dog shakes a rat" (Amis, 1984, p. 250).

The above-mentioned condition explains the prevailing atmosphere surrounding the human life in general because as the name implies, John Self may stand for anybody or any person living in the time frame being described above. This is quite clear when he is asked about his name, Self says "I'm called John Self. But who isn't?" (Amis, 1984, p. 97). Due to the effects of money on them, most people are striped out of all the noble senses of humanity and sublimity. Lorne Guyland, the deceitful character who fools John Self throughout the novel, describes the world by saying, "it's a terrible world we're living in, John, it's a really crazy, awful... world" (Amis, 1984, p. 107). In this tragic world there is little room for positive role of family ties and kinship. It is a human instinct to resort to family members and 
close friends in case of difficulties and need but Self is having little support in this direction. Very little is known about Self's childhood except that his "mother died when [he] was very young. She died when she was very young too" (Amis, 1984, p. 74).

Self also explains that it was not only the death of his mother that deprived him from the affection and care of the family but his father's treatment is also void of any parental emotion. Self says that "few fathers have abused their sons as Barry Self has abused me" (Amis, 1984, p. 262). He refers to Barry as a "funker" because, in addition to negligence and improper paternal care for a child whose mother is dead, Barry is claiming every single pound spent on his son's upbringing as per a written statement. This is how society values human beings and how individuals appreciate each other based on the amount of money that one has. Being under the influence of such atmosphere where money is everything in life, Self is trying to make a lot of money through his TV advertising film which is the only reason why he has travelled to New York. While staying in New York he meets Martina Twain who is "class, with a terrific education" (Amis, 1984, p. 41). She starts to see Self more often and decides to educate him by giving him some books to read. One of these books is George Orwell's Animal Farm. This book allegorizes the condition of a world where the powerful and wicked are in full control of the fate of the other knowledgeable and straight people.

In the world of Money, even the noble relationships between men and women are almost completely based on interest and material gain. He points to the kind of a relation between Self and his girlfriend Selena as being void of any human affection. Self admits that Selina has an excellent system for love. She is always ready to go to bed with him when he "shout[s] at her a lot or threaten her or give her enough money" none of which is based on human affection. Self, on the other side, is also having this relationship with Selina because he hasn't so much money at that time. He is not hiding his intention to leave Selina and pal another girl as soon as he gets lots of money. This money-based relation seems to be the case for most of the female characters in the novel. Caduta Massi for example, is forty-three and has children yet, she finds herself forced to work as a porn actor against her will. She is begging Self for protection because "she doesn't want to take her clothes off", but the surprising answer Self gets from her co-actor, Lorne Guyland, is "what do you mean she won't take her clothes off.' she's only a f***ing tv actress/ i'll rip her $\mathrm{f}^{* * * i n g ~ c l o t h e s ~ o f f ! ~[a s t e r i s k s ~ a r e ~ m i n e] " ~(A m i s, ~ 1984, ~ p . ~}$ 105). Even Martina Twain, the educated and sensible female character who Self had benefited much from her friendship is complaining about lack of human touch in her life.
Under such a dire condition, described above, many people's dream would be restricted to having money and they never hesitate to do anything to achieve that goal. They adore money and are enslaved by it. This is how Self has become when he tells Martin Amis, a character in the novel, that "Selina says I'm not capable of true love. It isn't true. I truly love money. Truly I do. Oh, money, I love you." (Amis, 1984, p. 221).

All these sad and unstable childhood and adulthood misfortunes has pushed Self into a status of a crisis which results in an extravagant and a low life-style that is mostly restricted to pornography, drink, fast-food, and sex. He starts to understand the real worth of money when he says "money is the only thing we have in common. Dollar bills, pound notes, they're suicide notes. Money is a suicide note" (Amis, 1984, p. 112). The condition is so horrific that he feels lost and believes that his life is not real when he states "how can you live seriously if you don't know who you are?" (Amis, 1984, p. 362). It is clear that Self is living in a status of identity crisis because he doesn't know who he is. While he swims in this bottomless sea of money and pleasure seeking for quite a time following his false hope of fame and success as a film director, he is shaken by the bitter reality of finding that he is running after a mirage in the mid of a desert. He is shocked to discover that his best friend, Fielding Goodney, is entrapping him in debts and loans instead of contracts of work.

It is time for Self to change his ways and starts a new as a new born person because "unless a man is born anew, he cannot see the kingdom of God" (Amis, 1984, p. 134). However, the process of change and rebirth is not easy and is mostly accompanied by pain and suffering as being described by Self when saying, "obviously it hurts, being born: that's why you scream and weep" (Amis, 1984, p. 117). For Self, who is now ready for the makeover, an old man ignites the fuse by saying "it is never too late ...to change your ways".

Self is facing new challenges in his transitional phase which can be felt as a split in personality. Part of his mind and thinking is directing him for his old ways in life while the other part is demanding the new direction. Thus, he says that "it seems there is a little man living inside me who acts as minister or propagandist or concessionaire.... There is an opposed, paramilitary unit in me too which feels the opposite way" (Amis, 1984, p. 290). Self is by now ready to leave his past life behind and look for a brighter future ahead when says, "God I can't wait to leave this moneyworld" (Amis, 1984, p. 335). After discovering the true worth of money, Self is eager to step out of the corrupt world of money. Luckily there is somebody who can offer help in the process. Martina Twain is the one who has a very great role in assisting Self to recognize the true meaning of life and the real worth of his existence. 
While no longer being controlled by money, Self can tell the real worth of everything in his surroundings. It seems that he has learnt the real power of TV and adgame. It is through TV that peoples' minds are controlled, speaking strictly in the context of the novel which is 1980s. He begins to appreciate books and spend time in libraries especially towards the end of the novel when he undergoes unemployment period. Self says, "I read quite a bit. It's the only diversion I can still afford.... I hang out in the Library. The Library is a good place when you're unemployed. It's warm and free. There is shelter" (Amis, 1984, p. 357). It is impossible to neglect money altogether even if one tries his best. This is why he says, "if we all downed tools and joined hands for ten minutes and stopped believing in money, then money would no longer exist. We never will, of course" (Amis, 1984, p. 354). This is somehow prophetic since if everybody gives money its real worth, money would lose its demonic status but this is impossible to be done.

In addition to the mental and behavioral change, John Self has also discovered something very peculiar and unexpected on his genealogy. The surname he was using for thirty-five years turns out to be unreal. Barry Self, the person whom John has known to be his father is now ready to disclose the long-waited secret. It seems that it was not easy for Barry to hide this secret for such a long time but that he might have waited for a suitable time to disclose it. Barry tells Self that Fat John is his real father.

John is now more sophisticated and knowledgeable after gaining good experience about life and people in the world. John is, by now, looking more human and thus, he writes to Selina and shares his intention to "raise that child of hers as if it were [his] very own" (Amis, 1984, p. 357). According to Erikson's identity theory those who care about others and try to help other people have good life are believed to have achieved generativity which is an indication of having a healthy identity in adulthood.

Martin Amis's second novel, London Fields, which has been published in 1989, is one of Amis's most successful works of 1980s (Pesetsky, 1990; Scura, 2013). According to Gavin Keulks (2006), London Fields together with Money are "two of the decade's most incisive portraits of apocalyptic anxieties, nuclear fear, and bristling individualism" (p. 2). The author tries to reflect on the daily problems of the time through carefully selected characters who act and interact to present the audience with a real-life experience. It is a story of Samson Young, an American writer, who comes to London to write his book and swaps his residence with Mark Asprey of the same occupation. During his stay in London, Samson comes to know the main characters of the novel who are paying recurrent visits to a local pub named Black Cross where most of the actions take place. Nicola Six, who is thirty-four and extraordinarily expects get murdered by either of the two other male characters, Keith Talent, a cheat, or Guy Clinch, a wealthy and honourable gentleman.

London Fields is a murder story based allegorically on the death of love and the prevalence of a constant quest of individuals to find an outlet from the doomed apocalypse and destruction brought about by material greed and lack of spirituality. "If love was dead or gone" states Amis, "then the self was just self, and had nothing to do all day but work on sex. Oh, and hate. And death" (Amis, 1989, p. 298). In Amis's perception, the world is destabilized and having a crisis when he says, "even the Old Testament expected the Apocalypse 'shortly'. In times of mass disorientation and anxiety... Will it reach the conclusion it appears to crave - will the Crisis reach the Conclusion?" (Amis, 1989, p. 64).

The crisis that Amis is referring to is the consequence of certain anomalies that have their "immemorial work of making everyone look and feel like shit" (Amis, 1989, p. 26). The impact is so heavy on humans as well as on the planet that durability and life circle of everything shrink and one feels that time has shortened. "Really the thing about life here was its incredible rapidity" that make "people growing up and getting old in the space of a single week. Like the planet in the twentieth century" (Amis, 1989, p. 36). People are so deeply involved in self destructive activities like environmental pollution and lack of love that they make the planet look like a sick person.

Besides environmental pollution there is political tension and war that leave huge impact on human condition. They are having devastating short- and longterm consequences. Amis calls some of them proxy wars where super powers are engaged directly or indirectly often to test their newly invented weapons and gain ignominious profit from weapon sales. The author is sharing his criticism against the human cruelty when it comes to the invention of weapons of mass destruction on top of which is the nuclear bomb. He refers to the World Wars and how humans removed their masks and revealed their true face. He points to the American use of nuclear weapon when saying, "What American men did there - one of the greatest crimes in human history. If you got the world's most talented shits and cruelty experts together, they couldn't come up with anything worse than Bikini" (Amis, 1989, p. 127). What the author is very much surprised about is that humans have named a woman underwear after this notorious catastrophe. Nicola tells Keith, "and how do we commemorate the crime, Keith?' ... 'Certain women go about wearing this trash. It's very twentieth-century" (Amis, 1989, p. 127). This would indicate that twentieth century is a weird time during which humans take illogical decisions. Nicola explains that she has looked for a link between the two in Brewer dictionary and that 
the only shared quality is "the devastating effects of the explosion and the devastating effects of the costume" (Amis, 1989, p. 127). Brewer has explained it well since both have very devastating effects on human life in general and men specifically. Nicola's manipulation of Keith, Guy, and to certain extent even Samson, is a clear representation of this fact. To this direction, Nicola is comparing herself to "a black hole [that] nothing can escape from" (Amis, 1989, p. 67).

Amis is tackling a very important issue, here in London Fields as in Money, which is the position of women in the twentieth century and how they have been abused to show up and work in sex industry including pornography. Amis is harshly criticizing what he calls "imperialism" for making the wide world as a "brothel" (Amis, 1989, p. 199). He presents this case through Nicola's claim that she had slept with Shah of Iran and telling the details of the event and the reason why she had accepted the offer. Once again money is used as a seduction to entrap women into this inhuman business. The customers offer such a big amount, in case of Nicola " $\$ 50,000$ " for "one night with the Peacock", that is usually hard to be refused. Those sex buyers have teams in different places of the world whose work is to find and recruit beautiful women for their masters (Amis, 1989, pp. 198 - 199).

Reducing women into sex toys for the sake of gaining more wealth by the sex profiteers is also exacerbated by involving underage females in this humiliating transaction. It is quite disturbing to find out that in some cases even close family members like parents are participants of the crime. Amis mentions the case of Debbee Kensit who is one of Keith's girlfriends by saying that "Debbee was 'special'. Debbee was special because Keith had been sleeping with her since she was twelve years old. On the other hand, so had several other people". The special thing about this girl is not only that she is very young but also "because she'd had her tubes done" which means that she has surgically treated her ovaries and is not going to have reproduction issues. In this case the transaction is very easy: "you just gave cash gifts of seventy-five quid to her mum" (Amis, 1989, p. 51). In Debbee's case, it is her mother who runs the business while on a bigger scale there are institutions involved, as Amis puts it, in this "strongly criminal" industry (Haffenden, 1985, p. 21).

Related to the case of women is also the issue of pornography which Amis refers to it as "the dirty little secret ... starting as samizdat and ending up as a global industry" (Amis, 1989, p. 295). This industry has a tremendous impact on modern humans, the like of Keith Talent who spend "between two and three hours a day in a largely fruitless quest for the sort of pornography [they] liked" (Amis, 1989, p. 295). People have got addicted to pornography in the same way as some are addicted to drugs. Keith is a good example when he says "that he had no resistance to pornography. He had it on all the time, and even that wasn't enough for him. He wanted it on when he was asleep. He wanted it on when he wasn't there" (Amis, 1989, p. 295).

Amis declares that women disapprove of pornography since apart from the humiliation to the female sense and feelings, "women talk about the violence it does to them". According to Nicola, "it excludes them. Women are there when pornography is made. Ruined sisters. But they're not there when pornography is used. That's men's work. They don't share their little secret with women. They share it with pornography" (Amis, 1989, p. 295). All these devastating effects of pornography and falsification of truth are made possible by advertisement through media generally and TV specifically. TV is politically and economically directed to control the public opinion and make-believe scenarios to achieve its desired role in the community. For Keith, TV is a "modern reality" or "the world" since he believes in all that comes from it. "TV came at Keith like it came at everybody else" Amis states "and he had nothing whatever to keep it out. He couldn't grade or filter it. So, he thought TV was real" (Amis, 1989, p. 55).

In London Fields, Amis blames capitalism for treating individuals like toys or puppets having no control on their mindsets. In the age of mass media and communication technology ordinary people are easily drifted and played upon. Nick Bentley (2008), citing from the post-Marxist critic Louis Althusser, in Contemporary British Fiction states that "under capitalism, people are not only politically exploited, but that their psychological frameworks are such that they are unaware of their exploited condition" (p. 39). Keith is a typical example of this manipulation and exploitation since his life is a continuous search for money through cheating, burgling, and other illegal activities to spend it on sex, pornography and liquors. He has no idea how he has been used and exploited in his daily life.

To clarify this gloomy and scandalous condition prevalent at the end of the millennium, Amis metaphorically refers to the twentieth century as a vicious enemy who is predetermined to exterminate all the human beings. "And now the twentieth century had come along", he states, "and after several try-outs and test-drives it put together an astonishing new offer: death for everybody" (Amis, 1989, p. 297). In addition to being a scathing commentary on different aspects of life in 1980s, London Fields also deals with issues related to destabilized identities of the main characters in the novel. Identities fall apart and are forced to adapt to the surrounding forces affecting them under the rapidly changing world. Each of the main characters is 
struggling to assert his/her presence and trying in vain to keep a form against the vortex of demolishing effects of what is called modernity.

The character who appears most in the foreground throughout the novel and Amis is telling every detail about, is Keith Talent. Bette Pesetsky (1990) thinks that Keith "represents Mr. Amis's best creation in the book... Born into poverty and emotionally without resources" (p. 3). He has no education and without employment but married and has a daughter. He gets a lot of money, "three times more than the Prime Minister" (Amis, 1989, p. 6), by cheating and burgling but he spends it all on drink, sex, and pornography. "Television was the great shopfront" where he gets all his knowledge and entertainment. However; he aspires to achieve fame and wealth by playing darts. Keith has no stable identity. He continues to shift from one occupation, mostly illegal, to another starting with armed robbery, changing to racketeering, and ending up as a cheat. Despite being married he keeps his relationship with several women including the under-aged Debbee Kensit. At the beginning of the novel, the audience is made to think of Keith as a possible murderer of Nicola Six who predicts her death and looks out to find the perpetrator. But Keith, as Amis says, "didn't look like a murderer. He looked like a murderer's dog" (Amis, 1989, p. 9) as an indicator for his desperate situation. The metaphor is well applicable if we consider how a dog owner controls the dog by giving it pieces of bones same as Nicola controls Keith by giving him porn films in which she stars.

Keith is a clear depiction of the spirit of the age: bankrupt, reckless, and a wife-beater with no support from his surroundings. "Remember", Amis explains, that "he is modern, modern, despite the heels and the flares" (Amis, 1989, p. 97). He is threatened that his finger will be cut off if he does not pay back his debt and the only person who offers him help is Nicola. Keith is ready to change his ways if only there is some outside support. As soon as he feels that Nicola is on his side, he wins the dart competition and becomes a new person. Amis describes the new condition by saying, "the taste of victory is sweet" and this is why at that night "it was a new Keith Talent they were looking at" but Keith admits that "She did it. Nicky did it. Old Nick" (Amis, 1989 , p. 385). Keith also departs from his women because they have got either disappeared or they are following their own business with somebody else. He even writes his diary in which he states "Got to stop hurting K. No good" (Amis, 1989, p. 370). This is a clear indication that Keith is gaining self recognition and moves in the right direction towards building a stable and a true identity.

The other important character is Nicola Six who is "tall, dark, and thirty-four, it was bound up with a delusion, lifelong" (Amis, 1989, p. 15). She knows what is going to happen next and most of the time her foretelling comes true like the case of her parent's death in a plane crash. Similarly, she expects her own murder soon but does not know exactly who is going to do it. As a young person living in the twentieth century, she has tried different types of works to make her living. "In the more distant past", Amis states, "she had worked as a publisher's reader, a cocktail waitress, a telephonist, a croupier, a tourist operative, a model, a librarian, a kissogram girl, an archivist, and an actress" (Amis, 1989, p. 19).

Like most of the characters in the novel, Nicola also does not have a stable identity. Her presence is paradoxical since according to Nick Bentley, "as the designated murderee, her only function is to die and yet she is the enigma round which the plot is organized" (Bentley, 2008, p. 43). She wears different masks when interacting with the male characters either "to get through men - to get to the end of men" to destroy them or to satisfy her own fantasies. She plays the role of a pure and a virgin with Guy while with Keith she is a porn star. Nicola is the victim of her age. She is left helpless in a cruel world without any support from family or friends. Her parents who might have been of some kind of help to her are dead. She is left alone without brothers, sisters or any close kinship. She suffers so much that she invents in her mind a vicious friend named Enola Gay who has a child called Little Boy. Guy later discovers that

Enola Gay was the plane that flew the mission to Hiroshima. The pilot named the aircraft after his mother. He was once her little boy. But Little Boy was the name of the atom bomb. It killed 50,000 people in 120 seconds. (Amis, 1989, p. 445)

Nicola is going to die at the end of the novel but before her death she has helped Keith to change his ways, has managed to urge Guy to focus on his own family, and on top of all, she has been able to drag Samson and make him a character in the novel while at the beginning Sam thought himself to be the author. Amis is pointing to this fact when he tells, in Samson's words, that "she outwrote me. Her story worked. And mine didn't" (Amis, 1989, p. 466).

Amis tries to depict life in its broadest angle when he brings characters to represent the different layers of the society. Keith Talent represents the lower-middle class together with Nicola Six while Guy Clinch is made to be the voice of a high-middle class. Guy has all the attractions a modern age can offer, "a tremendous amount of money, excellent health, handsomeness, height, a capriciously original mind". Although he owns all the materialistic pleasure in life, "he was completely desperate, as many of us are these days. In a modern city, if you have nothing to do (and if you're not broke, and on the street), it's tough to find people to do nothing 
with" (Amis, 1989, p. 41). His wife spends a good time in bed but without him and this is why when Guy intends to go out, she says, "and where do you think you're going?" Guy replies, to "See some life" (Amis, 1989, p. 86). It is not only Guy who seeks some freedom outside the dull atmosphere of his household since his wife, Hope, also befriends with a tennis player named Dink Heckler. Guy thinks that there might be a sort of closeness between the two and this feeling torments him a lot. After trying his best with Nicola and spending a lot of money out of good will and naivety Guy is told to seek forgiveness from Hope's mother in New York and to confess to his wife. Towards the end Guy starts to learn that family is first and if one tries to look for happiness, he/she must look for it in the family. Samson says that "Pale Guy will go home, on his hands and knees". Samson also makes Guy to undertake the responsibility of Kim, Keith's small child. Finally, Guy manages to overcome his crisis of identity and follows the right path in life which is trust, love and humanity.

\section{TRAUMA OF MODERNITY}

Money is Martin Amis's depiction of the traumatic mental and psychological feelings of its protagonist, John Self. Despite having money and being able to spend it on what is considered to be luxuries of the modern time like food, drink, travel and sex yet, deep inside, Self feels unsecure and tries to collect more money thinking that this might bring him security and stability. Self shares this feeling right from the beginning of the novel to inform the readers about his traumatic psychological situation when he states, "now I'm just waiting. Things happen to me. They do. They just have to go ahead and happen. You watch - you wait..." (Amis, 1984, p. 9). Waiting, in itself, is a cause of stress and anxiety but waiting for something fearful to happen is even more disturbing. Fear is what Self feels and speaks about at the very beginning of his story. According to him, the whole world is indulged in fear when he says, "fear walks tall on this planet. Fear walks big and fat and fine. Fear has really got the whammy on all of us down here" (Amis, 1984,pp. 9, 10)

This prevailing condition of fear and uncertainty is not only related to the protagonist of the novel since he is confessing that this is the case for everybody. People fear losing everything in life if they don't protect themselves with the shield of money because in the materialistic world all the relations are based on interest. The most honorable relations like the familial links, the marital bonds, and friendship are all dependent on money and gain. Self's assumed father, Barry, is charging his son money for upbringing him. Selina Street, Self's girlfriend, is staying with Self for money. Fielding Goodney, Self's friend and co-producer of films, is not only seeking a mutual interest in working with
Self but he is intentionally entrapping Self in debts to make money.

Self is trying to compare his world to that of George Orwell's Animal Farm where the good animals are having no role while the bad and the aggressive ones are enjoying themselves. He tries to find out where his position fits in this allegorical world that represents the real world of the twentieth century. First, he says his life is like "One of the rats" but soon he revises his comparison and thinks of something different. This time he confidently says, "I am a dog. I am a dog at the seaside tethered to a fence while my master and mistress romp on the sands. I am bouncing, twisting, weeping, consuming myself" (Amis, 1984, p. 193). This image is very self-expressive since the owners are amusing themselves and entertaining the extravagant life of the seashore while the dog is tied to a fence and cannot move freely even to enjoy its animalistic pleasures. This movement restriction and confinement is so affecting the mental condition of the dog (simple and moneyless humans) that it melts down from within. Those dogconditioned humans are suffering mentally due to the lack of equal opportunity to access money and life facilities like the masters and mistresses who can spend happy times whenever and wherever they like. The consequence is "twisting, weeping, and consuming" one's self because "there is activity - and play, and thought and fascination - just beyond the holding rope" (Amis, 1984, p. 193).

Amis is also depicting Self's mental torture when he points to the fact that money is so close to everybody that people think they can get it very easily while it is not possible for them as if one is looking into it from behind a transparent wall of glass. People can feel money and they can see it around but they cannot get it since it is only available for few and the majority is deprived of it. According to Amis, "life is hoarded elsewhere by others. Money is so near you can almost touch it, but it is all on the other side - you can only press your face up against the glass" (Amis, 1984, p. 144).

Self is describing his traumatic mental status as a result of that horrible life condition when he says, "the mind was suffering too. Yes, the mind had its sufferings also. It was crammed with sin and crime" (Amis, 1984, p. 121).

The consequence of all that pressure and psychological distresses is enormous and exposes the helpless individuals to nervous breakdown. This is exactly the case for Self who declares "I was going insane. I was dying. That was what I was doing, dying" (Amis, 1984, p. 126). This tormenting inner feeling of helplessness and alienation is making people lose hope and see life as a lost battle. People give up fighting for their rights and get disappointed about any chances of 
correction. Self speaks in the name of his generation and says,

We are all receding - waving or beckoning or just kissing our fingertips, we are all fading, shrinking, paling. Life is all losing, we are all losing, losing mother, father, youth, hair, looks, teeth, friends, lovers, shape, reason, life. We are losing, losing, losing. Take life away. It's too hard, too difficult. We aren't any good at it. Try us out on something else. But shelve life. Take life off the stands. It's too fucking difficult and we aren't any good at it (Amis, 1984, p. 253).

In order to escape this void and empty life, people think about suicide which tells the level of calamity humans are facing. Lack or scarcity in finance, depression, and insufficient social support might be among the very reasons why people may resort to selfhurt and suicide in the modern time. According to Marta Miret and Pilar López-García (2016), some of the common reasons for suicide are "losing a job, home foreclosure and financial problems" which "lead to an increase in the risk of suicide through comorbidity with other risk factors such as depression, anxiety and increased alcohol consumption" (p. 195). Affected and overwhelmed by such a feeling, Self says, "I must be very unhappy. That's the only way I can explain my behaviour. Oh man, I must be so depressed. I must be $\mathrm{f}^{* * *}$ ing suicidal [asterisks are mine]. And I wish I knew why" (Amis, 1984, p. 118). Self, having this suicidal behavior, is talking about committing suicide more than once in the novel. On his way back to London from New York, Self has also tried to end his life but it seems that fate is working against his will and doesn't allow it to happen.

John Self's traumatized position is not only the result of lack of money or search for collecting more of it. His social background as well as his childhood and teenage life also have played a great role in shaping his egoistic perspective which finally cause his breakdown. This is what Carlos Silva Campañón (2004) goes for when he says,

Self's familial background seems the perfect soil for all kind of psychosis; his loveless and motherless childhood, his coming of age at the Shakespeare, his father's strip pub, his deeply faulty and traumatic relationship with Barry Self, his fake father who is able to hand Self a bill for the money he has spent on his upbringing. (p. 91)

Amis has used the subtitle as a pun when he once referred to the suicide notes as been used for money note like dollar bills and pound notes while he also used suicide note to refer to the note John Self started to write at the end of the novel before he tries to commit suicide. This is how Self describes the situation by saying, "I wrote a suicide note, a short one this time. It just said,
'Dear Antonia, don't go into the bedroom. Go home and call the police. I'm sorry about your money. I'm sorry about all the mess". He tries to carry out his plan by swallowing "pills in fistfuls". He describes the process as being "like love you won't find on this world, and I wept and said, 'Do it. Take me. Oh, quick - take me.' But then I felt the last shame coming. Dah. My life was a joke. My death will be serious" (Amis, 1984,p. 350).

Amis's second novel, London Fields, is also a depiction of traumatic situations facing people in the twentieth century. Starting at the very beginning is the hesitation and fluctuation of the author to choose between the different alternative titles like Times Arrow, Millennium, The Death of Love, The Murderee, and London Fields for the work. It seems that the author has suffered much, "they cost me sleep", until he finally decided to settle on the current title for the novel. Besides this hesitation, there is a gloomy atmosphere prevailing in the novel from the beginning to the end and, in Samson's words, "brings [him] close to hysteria" (Amis, 1989, p. 14). This condition is presented in the description of the weather "Particularly the winds. They tear through the city, they tear through the island, as if softening it up for an exponentially greater violence" (Amis, 1989, p. 41). The clouds are "behaving so strangely these days". They have "gathered themselves into a single cylinder, east to west, like a god's rolled towel, like the slipstream of a plane the size of America" (Amis, 1989, p. 95). This condition is a reflection of the inner feelings of the writer and suggests the prevalent mood of depression that encompasses the whole story.

This bleak atmosphere is further supported by Samson's description of London city and how he sees himself fitting in it immediately after his arrival from New York by saying, "I woke up today and thought: If London is a spider's web, then where do I fit in? Maybe I'm the fly. I'm the fly" (Amis, 1989, p. 3). Amis is pointing at the difficulties facing people when they seek freedom and prosperity in moving to the big cities to get a better life by comparing them with the flies that are helplessly caught in the spider's web. As much as they try to move and free themselves, they are enmeshed more and more and chances of getting free are diminished further and further.

What is very traumatic for the characters in London Fields is death of love and Amis's choice to include this expression among the possible titles is a clear indication of the importance of this topic in the novel. Nicola is sure that "no one would ever love her enough, and those that did were not worth being loved enough by" (Amis, 1989 , p. 17). This lack of love may be one of the possible reasons why she has resorted to drink and sex as well as the increased fantasy of controlling men. Lack of love and understanding in the marital relationship is what leads Guy Clinch to feel empty at home and seek for 
love outside the family with Nicola. Guy believes that his wife Hope is betraying him with another person and suffers the bitterness of being skeptical about his wife although it turns out to be only baseless speculations. Guy's naivety makes him think that intimate relation with Nicola is perfect and based on love while in fact "he didn't know that she was just a weatherwoman, with stick and chart. For him it was the real thing. He didn't know that it was just an ad" (Amis, 1989, p. 413). Familial ties are at their worst position in the world of London Fields. Children are left astray to fight for their life alone in a cruel world or sometimes are abused even by their parents while old parents are left in nursing homes if they are lucky enough to be admitted to.

Hope disliked her mother, of course, and her mother disliked Hope; Guy had not seen Mrs Broadener for seven or eight years. The only thing he knew about this place, her last refuge, was a detail that Lizzyboo had let slip. (Amis, 1989, p. 427)

During his visit to the nursing home where Hope's mother, Mrs. Broadener, lives, Guy started to talk about the importance of family connectivity. The old woman remains silent except for one short but decisive comment that concludes the disastrous condition of the familial links of the time. She states that "it's all shit" (Amis, 1989, p. 427). Further to this point, Amis is questioning the true value of friendship and kinship that once upon the time people adhered to and made their life easier but in this chaotic time they are missing and those who try to stick to them are mocked upon. "Where are everyone's friends? Where's everyone's family? Where's Kath's family? Why isn't she smothered in sisters and mothers?" (Amis, 1989, p. 435), inquires Amis to highlight the value of these kind of support in one's life.

Nicola's traumatic life experiences early from childhood oblige her to think about an escape and thus, she has created a 'double' for herself naming it Enola Gay. Whenever Nicola is doing a bad thing, she always claims that it was Enola who is doing these things. While the presence of this double is used as a justification for her peculiar behaviors, it is also an indication that Nicola suffers from identity disorder. Enola has a child named Little Boy the same name as the atomic bomb which was used in WW II. The connection between the two seems to be the destruction of the self and the surrounding.

Enola didn't exist. Nicola invented her. When adolescence came Enola went and did a terrible thing. Thereafter she kept a terrible secret. Enola had borne a terrible child, a little boy called Little Boy. 'Enola,' Nicola would whisper in the dark. 'What have you done, you wicked girl? (Amis, 1989, p. 66)

One final traumatic reference in the novel is related to the position of writers and the development of the feeling of guilt when they create characters who suffer a lot in their works. Amis is feeling socially and morally responsible for his character's hardships and pain. Through Samson, Amis states that "I failed, in art and love. I wonder if there's time to wash all this blood off my hands" (Amis, 1989, p. 467). According to Amis, even fictional characters should be treated humanely and it is the responsibility of the author to take this into account while writing a work of art (Bentley, 2008, p. 43). This is also true for the readers because in the process of reading one finds him/herself compelled to involve emotionally with the character's sufferings even though one has no doubt that these characters are fictional.

\section{CONCLUSIONS}

Martin Amis, through poignant depiction of life in 1980s, has managed to draw his reader's attention to the harsh materialistic life style prevailing in Europe and America towards the end of the second millennium. A life style that thrust individuals towards greed, selfishness, and spiritual emptiness. In an atmosphere where money and wealth become the highest aim in life, love and kindness are replaced by cruelty and deceit. As a consequence of their inconsiderate behavior, humans are destroying their future and the future of their offspring for a very short-lived pleasure in the present.

In Money, John Self the protagonist is describing money as "suicide notes" because it is valued more than human noble emotions of love, kindness, and humanity. This over-estimation of money brings disaster and catastrophe to the whole world. In the world of Money, all relationships are based on interest including the familial ones. Humans are left to face the harsh and difficult choices of life alone and, in many cases to survive, they are forced to involve in illegal and inhuman activities like sex trade and pornography. This money-adoration issue is not only the case of people in London and New York, the two cities Self crisscrossing for his business, it is rather a world phenomenon proliferated by the capital system that left no corner of the world unconquered. After running for a long time after the phantom of money in vain, Self realizes that his life has become "like a joke" and thinks about committing suicide. Self's life changes drastically when he comes in contact with "Martin Amis", a character in the novel, and Martina Twain who guides him towards self-recognition and moderation in terms of the value of money in human life. Finally, Self is able to find out who is his real father and manages to find a loving partner with whom the relationship is not based on money.

Amis's second novel, London Fields, is also a critique of the modern life where humans are compelled to wear different masks behind which to hide their formless shapes. The characters are struggling to prove their 
existence against superpowers that crash everything comes into their way. The imbalanced confrontation results in fragmented selves and disillusioned individuals who are racing against time to satisfy the pleasures of the flesh and forget their wretched condition. Keith Talent is a good example of such individual who tries cheating, burgling, and handy craft works to provide for his drink and porn films. He is anti-education and women-abuser who spends a good deal of his time watching television. Nicola Six around whom a good part of the plot revolves is seeking her death and until then she is planning to get to "the end of men". Guy Clinch, the well-to-do aristocrat, has all the material pleasure but is suffering from emptiness and spiritual vacuum. He seeks love with Nicola and pays money generously out of charity to Nicola's presumed friend "Enola Gay". Samson Young who at first plays the role of the author but later turns into a character in Nicola and Asprey's book is finally making changes to the plot contrary to what the reader has expected from the beginning. He ends the book by becoming Nicola's murderer immediately before he himself dies as a result of his illness leaving the authorial credibility to Mark Asprey who shares the sameinitials with Martin Amis.

The message behind both novels is a noble one although it is expressed in a complex language and technique. Humans have instable identities as a result of a traumatic life conditions they are experiencing. The safe path to escape this instability is to avoid excess and think humanly beyond the temptations of modernity. However; the challenge remains whether they can follow the right path or not. Whether they can resist the temptations from within as well as from the outside or not.

\section{REFERENCES}

Amis, M. (1984). Money: a suicide note (2010 published by Penguin Books ed.). London: Jonathan Cape.

Amis, M. (1989). London Fields (1st Vintage International Edition April,1991- New York ed.). London: Jonathan Cape.

Bentley, N. (2008). Contemporary British Fiction. Edinburgh: Edinburgh University Press.

Berman, M. (1982). All That Is Solid Melts into Air: The Experience of Modernity. New York: Penguin Books.

Britannica, T. E. (Ed.). (2020, March 27). Martin Amis: British A u thor. Retrieved April 13, 2020, from Encyclopedia Britannica: https://www.britannica.com/biography/Martin-Amis

Campañón, C. S. (2004, December). Through the Looking Glass: America in Martin Amis's "Money: A Suicide Note". Atlantis, 26(2), 87 - 96. Retrieved March 26, 2020, from https:// www.jstor.org/stable/41055163

Craib, I. (1994). The Importance of disappointment. London and New York: Routledge.

Finney, B. (2008). Martin Amis. New York: Routledge.
Frosh, S. (1991). Identity Crisis, modernity, psychoanalysis and the self. New York: Palgrave Macmillan.

Giddens, A. (1991). Modernity and Self-Identity. Cambridge: Polity Press.

Haffenden, J. (1985). Novelists in interview. London \& New York: Methuen.

Keulks, G. (Ed.). (2006). Martin Amis: Postmodernism and beyond. New York: Palgrave Macmillan.

Lea, D. (2005). One Nation, Oneself: Politics, Place and Identity in Martin Amis' Fiction. In J. Acheson, \& S. C. Ross (Eds.), The Contemporary British Novel. Edinburg: Edinburgh University Press.

McCrum, R. (2015, June 29). The Guardian. Retrieved April 13, 2020, from The 100 best novels: No 93- Money: A Suicide Note by Martin Amis

(1984): https:// www.theguardian.com/books/2015/jun/29/100-bestnovels-93-martin-amis-money

Miret, M., \& López-García, P. (2016). Effect of Economic Crises on Suicide Rates. In P. Courtet (Ed.), Understanding Suicide from Diagnosis to Personalized Treatment (p.195). London: Springer International Publishing.

Mulalić, A. (2015). The Treatment of Violence in Martin Amis' Money and Pinters' The Caretaker. Epiphany: Journal of Transdisciplinary Studies, 8(1),57-67.

Pesetsky, B. (1990, March 4). Lust Among the Ruins. The New York Times Book Review. Retrieved March 23, 2020, from https://www.nytimes.com/1990/03/04/books/lust-amongthe-ruins.html

Scura, C. (2013, December). Martin Amis: London Fields 1989. Retrieved February 5, 2019, from London Fictions: https://www.londonfictions.com/martin-amis-londonfields.html 